\title{
PENGARUH PEMBIAYAAN MURABAHAH, ISTISHNA, MUDHARABAH, DAN MUSYARAKAH TERHADAP PROFITABILITAS (STUDI PADA BANK SYARIAH DI INDONESIA PERIODE MARET 2015 - AGUSTUS 2016)
}

\author{
Dewi Wulan Sari, Mohamad Yusak Anshori \\ Fakultas Ekonomi dan Bisnis, Universitas Nahdlatul Ulama Surabaya \\ e-mail:wulannawawi70@gmail.com
}

\begin{abstract}
This thesis aims to determine how much influence policy-contract agreement the Islamic bank financing (murabahah, istishna, mudharabah, and musyarakah) against the profitability of Islamic banks. Profitability used in this thesis is the Bukopin Syariah, BRI Syariah, BSM, and Muamalat Indonesia Bank. The data in this paper uses secondary data, monthly financial statements (balance sheet and income statement) in the period March 2015-August 2016. The financial statement has been taken from the publication of the report issues by the website of each bank. Mechanical of data management using multiple linear, regression, and test the classical assumption of normality test, multikoloniaritas, heteroksidasitas, and autokorolation, while proving the hypothesis of determination R2, F statistical test, and the test $T$ statistic.
\end{abstract}

Keywords: effect of financing, mudharabah, musyarakah, murabahah, istishna, profitabilitas, ROE, pengaruh akad pembiayaan

\section{PENDAHULUAN}

Saat ini perekonomian syariah mulai mendapatkan tempatnya, terutama pada sektor perbankan dengan menerapkan prinsip keterbukaan dan bagi hasil dirasa mampu memberikan keadilan bagi nasabah dan kestabilan bagi perbankan sendiri. Atas alasan tersebut sejak tahun 2007 perkembangan bank syariah mengalami peningkatan.

Meski demikian penetrasi keuangan syariah di Indonesia tergolong lemah. Data bank sentral Indonesia menunjukkan bahwa pangsa pasar bank syariah di Indonesia pada tahun 2015 hanya sebesar 4,61\% (BI, 2015). Keterbatasan modal merupakan salah satu tantangan yang dihadapi bank syariah untuk dapat bersaing di industri jasa keuangan. Untuk memperkuat modalnya, bank syariah perlu menawarkan sahamnya kepada publik.
Praktisi keuangan syariah, M. Gunawan Yasni (2015) mengatakan setidaknya ada empat urgensi bank syariah memerlukan investor baru. 1. Sebagian bank umum syariah (BUS) telah mendekati batas minimum rasio kecukupan modal (CAR)

2. Adanya kepastian bahwa jumlah pemegang saham minoritas di BUS maksimal 30\%.

3. Rencana bank sentral menjadikan BUS sebagai bank devisa jika BUS mencapai tier 1 (permodalan minimum Rp $1 \mathrm{~T}$ ).

4. Penargetan bank sentral untuk mengatur rasio efisiensi kegiatan operasional sebesar 85\%.

Empat urgensi di atas cukup menjadi alasan agar bank syariah mulai menawarkan sahamnya kepada umum melalui private placement atau bursa efek syariah. Untuk mewujudkan hal tersebut bank syariah perlu memperlihatkan profita- 
bilitasnya yang umumnya digambarkan oleh rasio ROA dan ROE.

ROA (return on asset) merupakan rasio untuk menilai seberapa besar kemampuan bank dalam mengelola asset untuk menghasilkan laba bersih. Sementara ROE (return on equity) adalah rasio untuk melihat seberapa besar kemampuan bank dalam mengelola modal untuk menghasilkan laba bersih. Melihat urgensi di atas, maka akan lebih tepat jika menggunakan ROE sebagai ukuran untuk melihat seberapa baik kinerja bank syariah dalam segi profitabilitasnya.

ROE dihasilkan dari perbandingan laba bersih dan modal, sedangkan laba bersih bank syariah terbesar didapat dari pembiayaan. Pembiayaan di bank syariah memiliki banyak akad, namun pada praktiknya yang sering digunakan adalah mudharabah, musyarakah, murabahah, dan istishna.

\section{KERANGKA TEORETIS}

\section{Pembiayaan Mudharabah}

Mudharabah adalah akad perjanjian antara dua pihak atau lebih untuk melakukan kerja sama usaha. Dalam akad mudharabah ini, pihak bank (shahibul maal) menempatkan modal sebesar 100\%, sedangkan nasabah (mudharib) berperan sebagai pengelola usaha. Bagi hasil dari usaha yang dikerjasamakan dihitung sesuai dengan nisbah yang disepakati bersama (Ismail, 2013:168).

Pendapatan yang diterima oleh bank dalam pembiayaan mudharabah ini adalah berupa bagi hasil dengan nisbah (porsi) yang telah disepakati bersama. Ada dua jenis bagi hasil yang diberikan kepada nasabah, yaitu revenue sharing dan profit/ loss sharing. Perhitungan revenue sharing berasal dari nisbah dikalikan dengan pendapatan sebelum dikurangi biaya. Sedangkan untuk profit/loss sharing, bagi hasil dihitung dari laba kotor. Dalam hal ini, bank biasanya menghendaki bagi hasil dalam bentuk revenue sharing (Darsono et al, 2016:287).

\section{Pembiayaan Musyarakab}

Musyarkah adalah akad kerja sama antara dua pihak atau lebih untuk suatu usaha tertentu di mana masing-masing pihak memberikan kontribusi dana dengan kesepakatan bahwa keuntungan dan risiko akan ditanggung bersama (Antonio, 2001:90). Musyarakah disebut juga dengan syirkah, yaitu sebuah aktivitas berserikat dalam melaksanakan usaha bersama antara pihak-pihak yang terkait.

Dalam pembiayaan musyarakah, bank syariah tidak memberikan modal secara penuh, akan tetapi modal yang diberikan adalah sebagian dari total keseluruhan modal yang dibutuhkan. Bank syariah bisa menyertakan modal sesuai porsi yang disepakati dengan nasabah, misalnya bank syariah memberikan modal sebesar $70 \%$ dari total kebutuhan modal, dan nasabah menyerahkan modal sebesar 30\% dari total kebutuhan modal.

\section{Pembiayaan Istishna}

Istishna merupakan akad kontrak jual beli barang antara dua pihak berdasarkan pesanan dari pihak lain, dan barang pesanan akan diproduksi sesuai dengan spesifikasi yang telah disepakati dan menjualnya dengan harga dan cara pembayaran yang disetujui terlebih dahulu (Ismail, 2013:146).

Akad istishna lebih tepat digunakan untuk membangun proyek, dan termasuk dalam jenis pembiayaan investasi. Mekanisme pembiayaan istishna dapat dilakukan dengan tiga cara, yaitu 
pembayaran di muka, pembayaran saat penyerahan barang, dan pembayaran ditangguhkan.

\section{Pembiayaan Murabahab}

Murabahah adalah akad jual beli atas barang tertentu pada harga asal dengan tambahan keuntungan yang telah disepakati oleh bank dan nasabah sehingga penjual (bank) harus member tahu harga pokok dan berapa keuntungan sebagai tambahannya (Antonio, 2001: 101).

Akad murabahah umumnya digunakan dalam transaksi jual beli barang investasi atau barang yang digunakan untuk pribadi, seperti kendaraan, rumah, mesin produksi, peralatan kesehatan, dan lain-lain. Akad ini lebih cocok digunakan untuk pembiayaan konsumtif dan investasi.

\section{Return on Equity}

Pada umumnya, rasio profitabilitas yang sering dipergunakan oleh bank untuk mengetahui kinerja keuangannya adalah return on asset (ROA) dan return on equity (ROE). ROA merupakan rasio untuk menilai seberapa besar kemampuan bank dalam mengelola aset untuk menghasilkan laba bersih, sementara ROE adalah rasio untuk melihat seberapa besar kemampuan bank dalam mengelola modal untuk menghasilkan laba bersih.

Beberapa literatur menjelaskan bahwa ROA lebih menggambarkan tingkat profitabilitas sebuah bank, khususnya bank syariah. Namun umumnya para stakeholder lebih melihat ROE untuk memprediksi tingkat pengembalian yang akan diperoleh. ROE menggambarkan return dari jumlah modal atau ekuitas suatu bank, semakin tinggi ROE maka tingkat pengembalian investasi pun semakin besar. Hal ini memungkinkan para pemegang modal untuk meningkatkan investasi di industri perbankan.

Karena penelitian ini didasari dari permasalahan modal yang dihadapi oleh bank syariah, maka profitabilitas yang akan digunakan dalam penelitian ini adalah ROE (return on equity). Rumus dalam menghitung ROE yaitu:

$$
R O E=\frac{\text { Net Income }}{\text { Equity Income }} \times 100 \%
$$

\section{Pengaruh Akad Pembiayaan Bank Syariah terha- dap ROE}

Dalam sebuah lembaga perbankan, sumber pendapatan terbesar yang diterima oleh bank adalah dari penyaluran pinjaman kepada masyarakat (kredit), dalam istilah bank syariah disebut pembiayaan. Berikut ini adalah akad-akad dalam pembiayaan bank syariah yang sangat beragam. 1. Skema jual beli memiliki tiga akad, yaiti murabahah, istishna, dan salam.

2. Skema kerja sama usaha memiliki dua akad, yaitu mudharabah dan musyarakah.

3. Skema sewa menyewa memiliki dua akad, yaitu ijarah dan ijarah muntahiyah bittamlik (IMBT).

Dalam praktiknya, pembiayaan-pembiayaan yang sering digunakan oleh bank syariah di Indonesia adalah dari skema jual beli yaitu murabahah dan istishna, serta dari skema kerja sama usaha yaitu mudharabah dan musyarakah.

Akad-akad pembiayaan yang dimiliki oleh bank syariah tersebut lebih memiliki kelebihan dibanding kredit yang ditawarkan oleh bank konvensional, salah satunya adalah tidak adanya sistem bunga dalam pembiayaan. Tidak seperti bank konvensional yang bunga pinjamannya sewaktu-waktu bisa berubah mengikuti fluktuasi BI rate, dalam pembiayaan di bank syariah sistem 
bunga tidak berlaku dan diganti dengan sistem bagi hasil dan margin keuntungan.

Hal tersebut yang membuat pembiayaan di bank syariah lebih diminati oleh masyarakat. Namun sayangnya tidak didukung dengan penetrasi pasar yang bagus, salah satu penyebabnya adalah keterbatasan modal yang dimiliki oleh bank syariah. Untuk menunjang modal bank syariah memerlukan suntikan dana tambahan dari investor.

Agar kegiatan usaha bank syariah berjalan efektif, bank syariah perlu melakukan evaluasi dengan melihat akad pembiayaan mana yang lebih memiliki pengaruh yang positif terhadap permodalan bank syariah. Dengan demikian bank syariah dapat memaksimalkan kegiatan usaha dengan meningkatkan penawaran pada jenis pembiayaan yang lebih memiliki pengaruh yang positif terhadap permodalan bank syariah.

\section{METODE PENELITIAN}

\section{Sample dan Prosedur}

Pengumpulan data dilakukan dengan menggunakan data sekunder yang diterbitkan dan dipublikasikan oleh BI. Data tersebut dapat diakses melalui www.bi.go.id. Data-data yang diambil adalah Laporan Keuangan bulanan bank umum syariah (Bank Syariah Bukopin, BRI Syariah, Bank Syariah Mandiri, dan Bank Muamalat Indonesia) mulai Maret 2015-Agustus 2016.

Data yang diperlukan adalah jumlah pembiayaan yang dikeluarkan oleh bank syariah yang informasinya dapat dilihat dari laporan neraca. Dan juga jumlah pendapatan serta modal untuk menghitung rasio profitabilitas ROE.

\section{Variabel Penelitian dan Pengukuran}

Dalam penelitian ini jenis variabel yang digunakan adalah variabel independen dan varia- bel dependen. Variabel independen disebut juga sebagai variabel bebas, di mana variabel tersebut memengaruhi atau yang memengaruhi variabel dependen (variabel terikat). Sedangkan variabel dependen sendiri adalah variabel yang dipengaruhi atau yang menjadi akibat karena adanya variabel bebas. Variabel yang digunakan dalam penelitian ini adalah jenis-jenis akad pembiayaan yang sering digunakan oleh bank syariah yaitu: 1. akad pembiayaan mudharabah

2. akad pembiayaan musyarakah

3. akad pembiayaan murabahah

4. akad pembiayaan istishna

Keempat variable tersebut merupakan variabel independen, sedangkan variabel dependen yang digunakan adalah ROE (return on equity) bank syariah.

\section{Analisis Regresi Linier Berganda}

Alat yang digunakan dalam perhitungan ini menggunakan SPSS 20, dengan menggunakan model penelitian:

$$
Y=\beta_{o}+\beta_{1} X_{1}+\beta_{2} X_{2}+\beta_{3} X_{3}+\beta_{4} X_{4}+\varepsilon
$$

Di mana:

$\mathrm{Y}=$ variabel profitabilitas $(\mathrm{ROE})$

$\beta_{\mathrm{o}}=$ konstanta

$\mathrm{X}_{1}=$ variabel pembiayaan mudharabah

$\mathrm{X}_{2}=$ variabel pembiayaan musyarakah

$\mathrm{X}_{3}=$ variabel pembiayaan murabahah

$\mathrm{X}_{4}=$ variabel pembiayaan istishna

= error term

Pengujian hipotesis yang akan dilakukan dalam penelitian ini ada beberapa tahapan, yaitu dengan menguji secara parsial $(\mathrm{T})$, uji simultan $(\mathrm{F})$, dan uji koefisien determinasi $\left(\mathrm{R}^{2}\right)$.

Uji parsial (T) digunakan untuk menunjukkan seberapa jauh pengaruh variabel independen 
dengan variabel dependen secara individual. Cara melakukan uji $\mathrm{T}$ adalah dengan membandingkan nilai statistik $\mathrm{T}$ dengan nilai $\mathrm{T}$ tabel. Jika nilai statistik $\mathrm{T}>$ nilai $\mathrm{T}$ tabel, maka $\mathrm{H}_{\mathrm{o}}$ ditolak. Jika nilai $\mathrm{T}$ statistik < nilai $\mathrm{T}$ tabel, maka $\mathrm{H}_{\mathrm{o}}$ diterima.

Uji simultan (F) menunjukkan apakah ada hubungan secara bersama-sama antara variabelvariabel bebas dengan variabel terikat, Cara melakukan uji $\mathrm{F}$ ini yaitu dengan membandingkan nilai $\mathrm{F}$ hitung dan $\mathrm{F}$ tabel. Jika F hitung $>$ F tabel, maka $\mathrm{H}_{\mathrm{o}}$ ditolak dan menerima $\mathrm{H}_{1}$.

Koefisien determinasi digunakan untuk mengukur seberapa jauh kemampuan model dalam menerangkan variasi variabel dependen. Nilai koefisien determinasi adalah antara 0 dan 1. Nilai $R^{2}$ yang kecil berarti kemampuan variabel-variabel independen dalam menjelaskan variabel dependen sangat terbatas. Nilai $\mathrm{R}^{2}$ yang mendekati 1 menunjukkan bahwa variabel independen member hampir semua informasi yang dibutuhkan untuk memprediksi variabel dependen (Ghozali, 2011:97).

\section{HASIL DAN PEMBAHASAN}

Hasil penelitian ini adalah variabel murabahah berpengaruh negatif terhadap ROE bank umum syariah dengan nilai koefisien -0,0000002281, variabel istishna memiliki hubungan yang negatif dan tidak signifikan terhadap ROE bank umum syariah dengan koefisien -0,00002204, variabel mudharabah berpengaruh signifikan dan positif terhadap ROE bank umum syariah dengan nilai koefisien 0,000003541, dan variabel musyarakah tidak memiliki pengaruh terhadap ROE bank umum syariah dengan koefisien 0,00000004583. Secara simultan keempat pembiayaan tersebut memiliki pengaruh terhadap ROE, hal ini sesuai dengan hipotesis lima atau $\mathrm{H}_{5}$ diterima.
Perhitungan semua variabel (mudharabah, musyarakah, istishna, dan murabahah)

Tabel 4.8

Regresi Pembiayaan Murabahah, Istishna, Mudharabah, dan Musyarakah

\begin{tabular}{|c|c|c|c|c|c|c|}
\hline \multicolumn{7}{|c|}{ Coefficients $^{\mathrm{a}}$} \\
\hline \multirow{2}{*}{ Model } & \multicolumn{2}{|c|}{$\begin{array}{l}\text { Unstandardized } \\
\text { Coefficients }\end{array}$} & $\begin{array}{c}\text { Standardized } \\
\text { Coefficients }\end{array}$ & \multirow{2}{*}{$\mathrm{T}$} & \multirow{2}{*}{ Sig. } & Correlations \\
\hline & B & Std. Error & Beta & & & Zero-order \\
\hline (Constant) & 2.748 & .523 & & 5.251 & .000 & \\
\hline murabahah & $-2.281 \mathrm{E}-007$ & .000 & -2.761 & -3.917 & .000 & -.209 \\
\hline istishna & $-2.204 \mathrm{E}-005$ & .000 & -.084 & -.729 & .468 & .046 \\
\hline mudharabah & $3.541 \mathrm{E}-006$ & .000 & 2.543 & 3.882 & .000 & -.086 \\
\hline musyarakah & $4.583 \mathrm{E}-008$ & .000 & .232 & 1.252 & 215 & -.332 \\
\hline
\end{tabular}

Suatu variabel dikatakan berpengaruh apabila nilai signifikan lebih kecil dari 0,05 , dari hasil perhitungan di atas variabel yang memiliki pengaruh signifikan terhadap ROE adalah murabahah dan mudharabah.

Persamaan yang diperoleh dari tabel di atas adalah sebagai berikut.

$\begin{aligned} \mathrm{Y}= & 2,748-0,0000002281 \mathrm{X}_{1}-0,00002204 \mathrm{X}_{2}+ \\ & 0,000003541 \mathrm{X}_{3}+0,00000004583 \mathrm{X}_{4}+\varepsilon\end{aligned}$

Persamaan di atas memiliki makna sebagai berikut.

a. Konstan $=2,748$

Nilai konstan sama dengan 2,748 artinya jika nila $\mathrm{x}$ (pembiayaan bank syariah yang menjadi variabel independen) sama dengan 0 , maka ROE sebesar 2,748.

b. Murabahah $\left(\mathrm{X}_{1}\right)=-0,0000002281$

merupakan nilai koefisien regresi variabel murabahah $\left(\mathrm{X}_{1}\right)$, terhadap ROE. Koefisien bernilai negatif artinya variabel independen memiliki hubungan terbalik dengan variabel dependen. Jika pembiayaan murabahah mengalami kenaikan senilai 1 , maka ROE mengalami penurunan sebesar 0,0000002281.

c. Istishna $\left(\mathrm{X}_{2}\right)=-0,00002204$ merupakan nilai koefisien regresi variabel istishna $\left(\mathrm{X}_{2}\right)$, terhadap ROE. Koefisien 
bernilai negatif artinya variabel independen memiliki hubungan berbalik dengan variabel dependen. Jika pembiayaan istishna mengalami kenaikan senilai 1 , maka ROE mengalami penurunan sebesar 0,00002204.

d. Mudharabah $\left(\mathrm{X}_{3}\right)=0,000003541$

merupakan nilai koefisien regresi variabel mudharabah $\left(\mathrm{X}_{3}\right)$, terhadap ROE. Koefisien bernilai positif artinya variabel independen memiliki hubungan searah dengan variabel dependen. Jika pembiayaan mudharabah mengalami kenaikan senilai 1 , maka ROE juga naik sebesar 0,000003541 .

e. Musyarakah $\left(\mathrm{X}_{4}\right)=0,00000004583$

merupakan nilai koefisien regresi variabel musyarakah $\left(\mathrm{X}_{4}\right)$, terhadap ROE. Koefisien bernilai positif artinya variabel independen memiliki hubungan searah dengan variabel dependen. Jika pembiayaan musyarakah mengalami kenaikan senilai 1 , maka ROE mengalami kenaikan sebesar 0,00000004583.

\section{PEMBAHASAN}

Variabel murabahah memiliki pengaruh signifikan dan negatif terhadap ROE dikarenakan pendapatan yang diterima bank syariah dari pembiayaan murabahah berupa margin keuntungan yang di dalamnya juga termasuk harga jual. Dalam sistem pembayarannya, nasabah dapat melakukan pelunasan langsung setelah menerima barang, atau nasabah dapat melakukan pembayaran secara bertahap. Dalam kenyataannya, nasabah akan membayar utangnya dengan cara angsuran.

Dalam pembayaran secara bertahap melalui angsuran, bank syariah dapat menaikkan pendapatannya dengan menaikkan margin keuntungan. Dengan kata lain semakin lama jangka waktu pembayaran, margin yang ditetapkan oleh bank syariah akan semakin besar, namun keuntungan diterima secara bertahap. Jika pelunasan dipercepat, maka pendapatan yang diterima bank syariah kurang maksimal sehingga akan berdampak pada profitabilitas (ROE).

Faktor lain yang menyebabkan profitabilitas turun adalah adanya risiko gagal bayar oleh nasabah. Semakin besar akad murabahah yang dilakukan, risiko gagal bayar juga semakin tinggi.

Variabel mudharabah juga memiliki pengaruh signifikan terhadap ROE. Mudharabah merupakan pembiayaan kerjasama usaha di mana bank syariah memberikan penyertaan modal 100\% kepada nasabah, dan nasabah sebagai pengelola usaha. Pendapatan yang diterima oleh bank syariah berupa bagi hasil dengan porsi bagi hasil sesuai kesepakatan. Pendapatan berupa bagi hasil jauh lebih besar dibanding pendapatan dari pembiayaan lainnya.

Dalam pembiayaan mudharabah, bank memberikan penyertaan modal secara penuh, hal ini akan memberikan persentase bagi hasil yang lebih besar bagi bank dibanding dengan jika bank memberikan pembiayaan musyarakah, di mana penyertaan modal dalam musyarakah, dibagi antara bank dan nasabah. Bagi hasil yang diterima bank dipengaruhi oleh hasil yang diperoleh oleh perusahaan, dan bank syariah hanya memberikan pembiayaan mudharabah kepada nasabah yang memiliki prospek bagus.

\section{SIMPULAN DAN SARAN}

Hasil penelitian ini menyebutkan bahwa dari akad pembiayaan yang dijadikan model variabel dalam penelitian ini, ada dua variabel yang memiliki pengaruh signifikan terhadap ROE, yaitu akad murabahah yang memiliki pengaruh signifikan dan negatif, juga akad mudharabah yang memiliki pengaruh signifikan 
dan positif. Sedangkan dua variabel lainnya yaitu musyarakah dan istishna tidak memiliki pengaruh yang signifikan terhadap ROE.

Dari hasil tersebut, Saran yang diberikan penulis kepada bank umum syariah dari melihat hasil penelitian ini adalah agar bank syariah dapat mengalihkan pembiayaan murabahah ke pembiayaan mudharabah karena pembiayaan mudharabah memberikan pengaruh signifikan dan positif terhadap ROE.

Pengalihan dari pembiayaan murabahah (jual beli) ke pembiayaan mudharabah (kerjasama usaha) secara tidak langsung mengajak masyarakat untuk terjun dalam sektor riil. Selain itu, bank syariah juga dapat mewujudkan tujuannya untuk menjadi lembaga yang berpihak pada sektor riil serta mendorong keutuhan segmen keuangan dan usaha produktif (Darsono, et al., 2016).

Pada kasus lain, apabila akad murabahah harus dilaksanakan, bank syariah harus membuat kebijakan baru mengenai hal-hal yang terkait pembiayaan murabahah. Hal ini dilakukan untuk menekan risiko dari pembiayaan murabahah, seperti risiko gagal bayar dengan cara pemilihan nasabah secara cermat dan selektif.

\section{DAFTAR RUJUKAN}

Antonio, M. Syafi'i. 2001. Bank Syariah dari Teori ke Praktik. Jakarta: Gema Insani Press.

Bank Indonesia. 2015. Retrieved September 2016, from bi.go.id: http://www.bi.go.id/ id/ruang-media/info-terbaru/Pages/Pengembangan-Ekonomi-Syariah-MemerlukanKerjasama-Pusat-dan-Daerah-ISEF2015. aspx

Basyir, A. 2014. blogspot. Retrieved September 2016, from blogspot.co.id: http://asyhar- notes.blogspot.co.id/2014/11/ketahananbank-syariah-dalam-menghadapi.html

Darsono, Astiyah, S., Harisman, Darwis, A., Sakti, A., Ascarya, et al. 2016. Perjalanan Perbankan Syariah di Indonesia. Jakarta: Bank Indonesia.

Fahmi, I. 2013. Analisis Laporan Keuangan. (D. Handi, Ed.) Bandung, Jawa Barat, Indonesia: Alfabeta.

Ghozali, I. 2011. Aplikasi Analisis Multivariate dengan Program IBM SPSS 19. Semarang: Badan Penerbit Universitas Diponegoro.

Ghozali, I. 2015. Aplikasi Analisis Multivariate dengan Program SPSS. Semarang: Penerbit Universitas Diponegoro.

Gunawan Sudarmanto. 2005. Analisis Regresi Linear Ganda dengan SPSS. Yogyakarta: Graha Ilmu

Hariyani, D.S. 2015. Analisa Kontribusi Pembiayaan Musyarakah, Murabahah, dan Ijarah Terhadap Profitabilitas.

Ismail. 2013. Perbankan Syariah. Jakarta: Pernada Media Grup.

Kristanto, B.A. 2016. Pengaruh Pembiayaan Mudharabah, Musyarakah, Murabahah, Terhadap Profitabilitas pada BRI Syariah di Indonesia. Surakarta.

Mamduh. M. Hanafi. 2003. Analisis Laporan Keuangan. Yogyakarta: Penerbit UPP AMK YKPN.

Otoritas Jasa Keuangan. 2016. Retrieved September 2016, from ojk.go.id: http://www. ojk.go.id/id/kanal/syariah/data-dan-statistik/statistik-perbankan-syariah/Pages/Statistik-Perbankan-Syariah-Mei-2016. aspx.

Peraturan Bank Indonesia No. 6/10/PBI/2004 Tentang Penilaian Tingkat Kesehatan Bank Umum.

Rahmah, G. 2015. Tempo. Retrieved September 2016, from Tempo.co: https://m.tempo.co/ 
read/news/2015/11/22/087721104/ini-7masalah-bank-syariah.

Singgih, S. 2000. Buku Latihan SPSS Statistik Parametrik. Jakarta: PT Elek Media Komputindo.

Wibowo, A. \& Sunarto. 2015. Pengaruh Pembiayaan Mudharabah dan Musyarakah Ter- hadap Profitabilitas Perbankan Syariah. Syariah Paper Accounting FEB UMS. Yoga, P. 2016. Info Bank. Retrieved September 2016, from infobank.com: http://infobanknews.com/tantangan-perbankan-syariah-di2016/. 